Int. J. Speleol. 10 (1978), pp. 205 - 209

\title{
The Discovery of Proteus-eggs (Proteus anguinus Laurenti, Amphibia) in Seminatural Conclitions
}

by

\author{
B. SKET and F. VELKOVRH ${ }^{(1)}$
}

The mode of reproduction of the only europen Proteide had for many decades been a complete mystery, supported by some contradictory da a (Nusbaum, 1907; Spandl, 1926). It can be said that Vandel and Bouillon (1 159) and Briegleb (1962) solved the problem conclusively. The following a dditional data can be of interest only because, a) they for the first time the va lidity of their findings for the natural conditions, b) they give some more e idence of the «Haupt-Ökotop» of the animal and c) they confirm the ovipa ity also for a morphologicaly distinct form of the species, P.a. zoisii (Fitzinger). In 1974 several non-biologist cave divers surprised us with the news about «a couple of hundreeds of young Proteus» in an accessory syphon of the Rakbranch of Planinska jama (Planina cave). In spite of its incredibility, th 2 news was so important, that we organised a «professional» diving expeditior two weeks later. We found there young fishes (Leuciscus sp.) and many sp :cimens of the cave-shrimp (Troglocaris schmidti Dormitzer). It seemed very probable, that the latter had served as a «model» for Proteus-larvae. After this discovery we began to pay more attention to the eggs and larvae of Proteus, but during the diving in the lakes and syphons of ecologically different cave-w iters, we never found a specimen of Proteus less than $10 \mathrm{~cm}$ long; not even in the cave Kompoljska jama, where relatively small specimens were found most times of the year. The smallest specimen ever found was $42 \mathrm{~mm}$ (after fixa ion in formaldehyde sol.) long juvenile (fig. 1), found in a pool of residual w iter in the cave Najadena jama in November 1964. The specimen is -except for he short snout and short gills - properly proportioned. The eyes are covered by only a thin layer of tissue and the skin is pigmented with a network of a sale gray cells.

\footnotetext{
${ }^{(1)}$ Institut za biologijo Univerze, YU 61001 Ljubljana, p.p. 141, Yugoslavia
} 
The Vir-spring at Sticna, $30 \mathrm{~km}$ ESE of Ljubljana (Slovenija, Jugoslavija), has been known for more than 100 years for bringing to the surface numerous, large specimens of Proteus after heavy rains. While trying to obtain the associated fauna we supplied the spring with some drift-nets. After the rainfall on 24. apr. 1976, we found in the net a Proteus-egg covered with clay. The embryo in it, corresponding to fig. 7/10 of Briegleb (1962) seemed to be in good condition, but after a day it showed signs of disintegration. If the taxonomic adherence of the embryo in that state was not completely reliable then the embryo found on 4. june 1976 confirmed our supposition. It was an egg, containing the embryo (fig. 2), corresponding aproximately to the fig $7 / 15$ in the above mentioned work. It was about $12 \mathrm{~mm}$ long and completely white. In order to prevent destruction, we preserved it in $70 \%$ ethanol.

The water of the Vir-spring has a locally normal «subterranean» temperature of $9,8^{\circ} \mathrm{C}$. Before the rain it was clear and with $9,25 \mathrm{mg} / \mathrm{l} \mathrm{O}_{2}$ about $80 \%$ saturated. The floods which brought to the surface the eggs (embryos) were not extremely strong and we did not find any adult Proteus in the water. In spite of that, the water was highly turbid, only a little bit warmer $\left(10,2^{\circ} \mathrm{C}\right.$ - the weather was extremely cold for june!)and with $7,8 \mathrm{mg} / 1$ only $68 \%$ saturated with $0_{2}$. The $\mathrm{BOD}_{5}$ of the clear water was about $1,7 \mathrm{mg} / 1$, corresponding to cleared sinking rivers. After the rain the BOD did not rise noticeably (to $2 \mathrm{mg} / 1$ ). However, the high water carried out much organic debris and living surfaceanimals (Gammarus $c f$. fossarum Koch, Pisidium sp., Sadleriana fluminensis / Küster, Hydra sp., etc.). It is difficult to say whether the animals were brought underground from an unknown small surface stream, or living in the spring itself. From our experiences (Sket 1970) it is known that Sadleriana does not penetrate actively upstream into the dark parts of springwaters. The subterranean fauna was represented - beside Proteus - by a few specimens of the Amphipod Niphargus spp. and some Gastropoda. The ratio between completely depigmented Niphargus cf. longiflagellum Karaman (orcinus-group) and Niphargus cf. podpecanus Karaman (stygius-puteanus-group) which is remarkably pigmented, was about 1:2. The strongly troglobitic Isopod Monolistra (Typhlosphaeroma) sp. was represented in the drift by one specimen only. The composition of the Molluscan fauna fits this schema also (Tab. 1). It should be noted the shape of the spring-outlet does not allow one to catch all the water neither to prevent reliably the input of organic debris from the neighborhood of the outlet into the drift-net.

The fact that the stronger floods flow even deeper into this habitat makes it obvious that the Proteus-eggs are not inevitably deposited in an environment with constant abiotic factors, as some author suppose (Briegleb, 1962; Istenic, 1971). Also the drifted fauna as a whole shows the characteristics of the fauna of energetically rich sinking rivers (Sket, 1970 for comparison) rather than that of clear subterranean waters. However, the total absence of Ephemerop- 
tera - and Plecoptera-larvae is a bit disturbing.

An additional interesting note is the area where the above menti ned eggs were found. It was from the same surroundings that the «Strati s protocole» concerning the viviparity of Proteus originated (Michaelles 183 ). It is worth mentioning that an aberrant form of Proteus is living in this a ea - from the spring Vir itself Fitzinger (cit. Schreiber 1875) has described the (species» $H y$ pochthon schreibersii and from the spring of Rupnica at Sticn: Hypochthon zoisii. The latter taxon is the only one accepted by some recent a thors as a valid subspecies of Proteus anguinus, and both localities are bu $2 \mathrm{~km}$ apart. Morphologically, the populations are almost identical. After $\mathrm{t} l \mathrm{e}$ above mentioned protocole, the newly caught Proteus - specimens had p oduced living young - so one could suppose, that a morphologically and bio ogically different race is living in the area of Sticna. The finding of the eggs makes us certain that oviparity is the normal reproductive way (or at least c ne of the normal reproductive ways) for the supposed race also.

Tab. 1 - The composition of the fauna drifted out of the Vir-spring together wi 1 the Proteus-fry. The numbers for Mollusca are not comparable with the numbers for other anim ils (different sampling net). The taxonomy of the Amphipoda is not yet accomplished and a reli ble determination not possible.

Surface animals avoiding subterranean habitats:

Sadleriana sadleriana (Clessin 1890) and S. fluminesis (Küster 1852)

(Gastropoda)

(10 specimens)

Surface-animals occuring \pm regularily in subterranean parts of sinking river

Hydra sp. (Hydrozoa)

Bythinella schmidti (Küster 1852) (Gastropoda)

Belgrandiella fontinalis (Schmidt 1847) (Gastropoda)

Pisidium personatum Malm 1855 (Bivalvia)

Pelescolex sp. (Oligochaeta)

Synurella ambulans (F. Müller 1846) (Amphipoda)

(with well developped eyes)

Gammarus fossarum Koch 1835 (Amphiphoda)

(many)

(15 specimens)

(many)

(many)

(10 specimens)

(1 specimens)

(10 specimens)

Subterranean animals occuring usually in the same type of habitats:

Niphargus cf. podpecanus Karaman 1952 (Amphipoda)

(35 specimens)

Subterranean animals occuring usually in the clear subterranean waters:

Hauffenia media Bole 1962 (Gastropoda)

Monolistra racovitzai ssp. (Isopoda)

Niphargus cf. longiflagellum Karaman 1950 (Amphipoda)

(10 specimens)

(1 specimens)

(15 specimens)

Taxonomically and/or écologically not defined or different animals:

Vorticellidae g.sp. (Ciliata, epizoic)

cf. Platycola sp. (Ciliata, epizoic)

Carychium tridentatum (Risso 1826) (Gastropoda)

Oligochaeta g.sp.

Cyclopoida g.sp.

cf. Candona sp. (Ostracoda)

Niphargus gr. tauri (Amphipoda) 


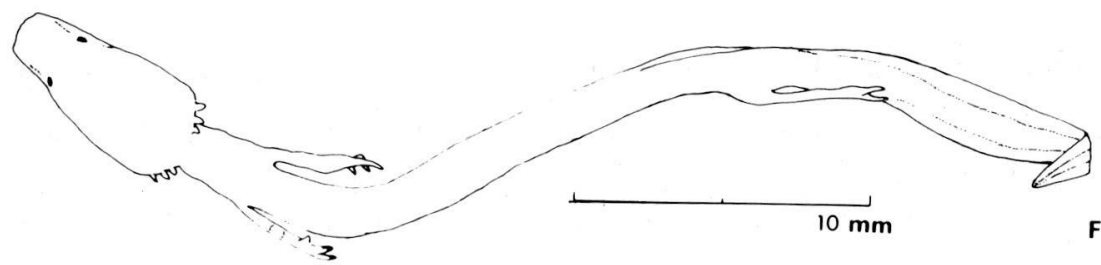

Fig. 1

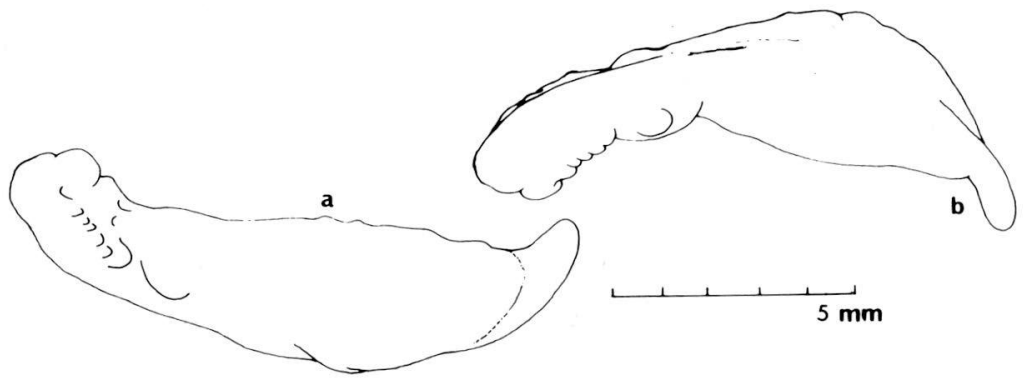

Fig. 2

Fig. 1 - Proteus anguinus Laur., Najdena jama near Planina (Slovenija), dorsal view of the smallest specimen found in the nature.

Fig. 2 - Proteus anguinus Laur., Vir-spring near Stiĉna (Slovenija), the older of both embryos found in the nature in the ventrolateral (a) and dorsolateral (b) view.

\section{SUMMARY}

Proteus-eggs were found for the first time in the nature, drifted out of a karstic spring. They were obtained from the Vir Spring at Sticna, $30 \mathrm{~km}$ ESE of Ljubljana. The hydrological and faunistical data indicate that Proteus lays its eggs also in «unsheltered», energetically rich groundwater habitats.

\section{RÉSUMÉ}

Pour la première fois, des oeufs de Proteus ont été récoltés dans la nature, après avoir été entraines par les eaux d'une source karstique. Ils proviennent de la source Vir à Sticna, à $30 \mathrm{~km}$ au SudEst de Ljubljana. Les résultats obtenus tant du point de vue hydrologique que du point de vue faunistique montrent que Proteus dépose aussi ses oeufs dans des habitats «non abrités» où les eaux souterraines sont énergétiquement riches.

\section{REFERENCES}

BRIEGLEB, W. 1962 - Zur Biologie und Ökologie des Grottenolms (Proteus anguinus Laur. 1768). Z. Morph. ökol. Tiere 51:271-334.

ISTENIĈ, L. 1971 - Izhodiŝsê za reŝevanje ekoloŝke problematike cloveŝke ribice (Proteus anguinus Laur. 1768) Biol vestink 19:125-130. 
MICHAELLES 1831. Beytrâge zur Naturgeschichte des Proteus anguines. Okı ts Isis pp. 499509.

NUSBAUM, J. 1907 - Ein Fall einer Viviparitat beim Proteus anguineus. B, l. Zentralblatt 27:370-375.

SCHREIBER, E. 1875 - Herpetologia europaea. Braunschweig 639 pp.

SKET, B. 1970 - Predhodno porôcilo o ekoloŝkih raziskavah v sistemu kraŝtle I ubljance. Biol. vestnik 18:79-87.

SPANDL, H. 1962 - Die Tierwert der unterirdischen Gewässer. Wien 235 pp.

VANDEL, A. et BOUILLON, M. 1959 - Le Protées et son intèrêt biologiquє Ann. Spèlèol. 14:111-127. 